\title{
PERANCANGAN ENTERPRISE ARCHITECTURE PADA FUNGSI SUMBER DAYA MANUSIA (SDM) DI UNIVERSITAS TELKOM MENGGUNAKAN TOGAF ADM
}

\section{DESIGNING ENTERPRISE ARCHITECTURE IN HUMAN RESOURCES FUNCTION OF TELKOM UNIVERSITY USING TOGAF ADM}

\author{
${ }^{1}$ Devi Nindya Murti, ${ }^{2}$ Yuli Adam Prasetyo, ${ }^{3}$ Asti Amalia Nur Fajrillah \\ 1,2,3Program Studi Sistem Informasi, Fakultas Rekayasa Industri, Telkom University \\ 1'devinindya28@gmail.com, ${ }^{2}$ y.adam.prasetyo@gmail.com, ${ }^{3}$ astiamalia@gmail.com
}

\begin{abstract}
Abstrak-Dalam meningkatkan pelayanan di bidang pendidikan yang didukung dengan adanya perkembangan teknologi yang semakin pesat, Universitas Telkom harus mampu menyelaraskan antara strategi bisnis dengan teknologi informasi, dimana pemafaatan teknologi informasi khususnya pada fungsi Sumber Daya Manusia (SDM) belum saling terintegrasi sehingga belum dikatakan secara maksimal. Oleh karena itu pada penelitian ini akan membahas perancangan enterprise architecture yang sesuai pada fungsi SDM Universtas Telkom. Dalam melakukan perancangan EA pada penelitian ini menggunakan TOGAF ADM yang terdiri dari fase preliminary phase, architecture vision, business architecture, information system architecture, technology architecture, opportunities and solutions, serta migration planning. Dari penelitian ini akan dihasilkan output berupa blueprint dari rancangan enterprise architecture pada fungsi Sumber Daya Manusia (SDM). Enterprise Architecture yang diharapkan dapat mempermudah pencapaian tujuan strategis yang sesuai dengan Fungsi SDM di Universitas Telkom dalam hal peningkatan fungsi bisnis, sistem informasi, dan teknologi informasi yang digunakan.
\end{abstract}

Kata kunci: Enterprise Architecture, TOGAF ADM, Sumber Daya Manusia

\begin{abstract}
Telkom University is the educational institution under the YPT (Yayasan Pendidikan Telkom) organization which focus on study programs in "Information and Communications Technologies, Management and Creative Industries" for science and art developing which based on information technology. Nowadays in the globalization era, Telkom University should be able to confront advances information system and information technology to compete in education world.In improve services in the education field with the rapid development of technology, Telkom University should be able to harmonize between business strategy and information technology. Especially on Human Resources function which focus on planning, improving, services, and evaluation. Enterprise Achitecture is method that can be used to synchronize it. In the Enterprise Architecture design is required a framework for developing the scope of discussion widely from any different involve business, data application, and technology. Framework used in this research is TOGAF ADM consisting of nine phases. However, only seven phase are used ie preliminary phase, architecture vision, business
\end{abstract}

architecture, information system architecture, technology architecture, opportunities and solutions, and migration planning. This research will produce the blueprint output from Enterprise Architecture design in the Human Resources module. Enterprise Architecture is expected to facilitate the achievement of business objectives that are compatible Human Resources function at Telkom University in terms of improving business functions, information system, and information technology used.

Keyword : enterprise architecture, TOGAF ADM, Human Resources

\section{PENDAHULUAN}

Pada era globalisasi, teknologi informasi dan sistem informasi memainkan peran penting dalam sebuah organisasi modern, dimana keselarasan antara strategi bisnis dan strategi IT diperlukan untuk mewujudkan organisasi yang efektif dan efisien [1]. Organisasi memiliki tingkat kompleksitas tinggi dalam menghasilkan sebuah value yang dilihat dari seg infrastruktur IT yang digunakan, keselarasan dengan tujuan strategis yang ditetapkan, dan meningkatkan komunikasi antara stakeholder bisnis dan stakeholder IT [2]. Dilain pihak, Enterprise Architecture merupakan pendekatan hirarkis yang hadir untuk menyelaraskan bidang bisnis dan bidang IT dengan mengintegrasikan proses bisnis, sistem informasi, fungsi organisasi, dan stakeholder dalam suatu organisasi, sehingga kegiatan yang berlangsung tidak hanya dalam ha pemenuhan kebutuhan yang mendesak tetapi juga membangun sebuah kemampuan [3]. Hal ini berlaku untuk setiap organisasi, termasuk lembaga Perguruan Tinggi yang tidak lepas dari hal bisnis dan IT selain berfokus pada mutu pendidikan. Oleh karena itu, perlu kerjasama antara EA dan standardisasi pada sektor ini [1].

Universitas Telkom adalah lembaga pendidikan yang berada di bawah badan penyelenggara Yayasan Pendidikan Telkom (YPT), dimana merupakan penggabungan dari empa institusi yaitu Institut Teknologi Telkom (IT Telkom), Poltek 
Telkom, Institut Manajemen Telkom (IM Telkom), dan Sekolah Tinggi Seni Rupa dan Desain Indonesia Telkom (STISI Telkom). Universitas Telkom memfokuskan program studinya di bidang "Information and Communications Technologies, Management and Creative Industries" dalam mengembangakan ilmu dan seni yang didasarkan pada teknologi informasi. Seiring perkembangan teknologi yang semakin canggih, Universitas Telkom bertujuan menghasilkan sumber daya manusia yang mampu bersaing dan berkompeten di bidangnya sebagai generasi penerus di bidang ICT [4]. Bidang ICT sendiri tidak lepas dengan adanya fungsi khusus yang bertanggung jawab dalam pengelolaan IT Universitas Telkom.

Direktorat Sistem Informasi (SISFO) Universitas Telkom (Tel-U) merupakan sebuah fungsi yang menjalankan peran dalam menunjang kegiatan akademik dan nonakademik, optimasi sumber daya, pengelolaan (otomatisasi) administrasi kampus, layanan nilai tambah dan daya saing, serta transformasi model pendidikan dan pengajaran [5]. Dimana saat ini Direktorat SISFO telah mampu memenuhi kebutuhan sistem informasi baik pada fungsi akademik maupun non akademik. Salah satu faktor pendorong pembangunan, pengelolaan, dan pengembangan sistem informasi pada Universitas Telkom adalah semakin meningkatnya kebutuhan sistem yang dijalankan untuk saling terintegrasi dalam satu sistem utama yaitu I-Gracias. Namun, dalam hal pemenuhan kebutuhan sistem informasi Universitas Telkom masih terdapat beberapa kendala diantaranya penerapan sistem informasi yang tumpang tindih, sistem yang dibangun belum saling terintegrasi dengan baik, serta pengelolaan database yang tidak terpusat. Kondisi tersebut memungkinkan sistem informasi tidak dapat dimanfaatkan sesuai dengan tujuan pengimplementasiannya yaitu menciptakan efesiensi dan efektivitas dalam penggunaan IT yang berpengaruh pada kinerja seluruh fungsi, salah satunya fungsi Sumber Daya Manusia (SDM) yang bertugas dalam perencanaan dan pengembangan resources.

Fungsi SDM merupakan fungsi utama untuk menjalankan misi organisasi yang memiliki peran penting dalam menghasilkan sumber daya manusia yang berkualitas. Dalam meningkatkan nilai tambah SDM, maka diperlukan definisi ulang peran HR, adanya pengembangan kompetensi baru, identifikasi aktivitas pendukung kegiatan operasional, dan pelaksanaan pendekatan secara menyeluruh pada entitas universitas [6]. Pada Universitas Telkom, fungsi SDM bertugas dalam hal yang berkaitan dengan perencanaan, pengembangan, pelayanan, dan evaluasi SDM. Saat ini dalam menjalankan aktivitas bisnisnya penggunaan teknologi informasi belum mampu menyesuaikan kebutuhan bisnis pada fungsi tersebut. Pada beberapa aktivitas bisnis yang dijalankan masih dilakukan secara manual, dimana kebutuhan TI belum mampu memenuhi atau menyelaraskan kebutuhan bisnis. Dalam hal ini dibutuhkan pendefinisian ulang mengenai kebutuhan TI untuk mendukung pelaksanaan aktivitas bisnis pada fungsi SDM. Pada pengelolaan layanan-layanan bisnis fungsi SDM memerlukan teknologi informasi untuk mempermudah kinerja bisnis. Fungsi SDM telah memanfaatkan teknologi informasi pada beberapa proses bisnisnya, namun belum berjalan secara maksimal. Hal ini dikarenakan belum ada keselarasan antara teknologi yang digunakan dengan kebutuhan bisnis. Permasalahan tersebut mengakibatkan kesulitan dalam pengelolaan data yang belum terautomasi, sehingga menghambat jalannya aktivitas bisnis, misalnya dalam pengajuan Jabatan Fungsional Akademik (JFA) yang dilakukan oleh dosen, dimana data pendukung tidak secara langsung dikelola pada sistem yang terpusat dan belum adanya sistem pelaporan yang terautomasi dari setiap proses bisnis yang dilakukan.

Oleh karena itu, perlu adanya perancangan Enterprise Architecture (EA) yang diharapkan dapat mempermudah dan memberikan solusi terhadap aktivitas bisnis yang dijalankan dan pengelolaan data fungsi SDM. Dimana dalam melakukan perancangan EA dibutuhkan sebuah framework arsitektur untuk mengembangkan lingkup pembahasan secara luas dari arsitektur-arsitektur yang berbeda meliputi bisnis, data, aplikasi, dan teknologi [7]. Framework yang digunakan pada penelitian ini adalah TOGAF ADM karena sesuai dengan bidang pendidikan, memiliki struktur yang sistematis, serta memiliki tahapan yang lengkap. Output yang dihasilkan pada penelitian ini berupa blueprint dari rancangan Enterprise Architecture yang diharapkan dapat mempermudah pencapaian tujuan strategis yang sesuai dengan Fungsi SDM di Universitas Telkom dalam hal peningkatan fungsi bisnis, data, aplikasi, serta teknologi.

\section{STUDILITERATUR}

Enterprise Architecture diartikan sebagai karya konseptual dan ilmiah yang bertujuan untuk membantu organisasi dalam berbagi pemahaman umum dari segi bisnis dan IT, serta menciptakan visi yang dilihat dari berbagai sudut pandang organisasi [4]. Begitu pula menurut pendapat dari Olsen dan Trelsgard, EA adalah gambaran suatu organisasi dilihat dari perspektif bisnis dan IT yang saling terintegrasi [1]. Sedangkan menurut pendapat A.Bakar, Harihodin, dan Nazri Kama, EA adalah pendekatan hirarkis untuk menyelaraskan antara strategi bisnis dengan strategi IT dengan mengintegrasikan proses bisnis, sistem informasi, fungsi organisasi, dan stakeholder yang terlibat di dalamnya. Tujuannya adalah mewujudkan visi dan misi, serta pencapaian hasil yang telah ditargetkan [3]. Berdasarkan definisi tersebut dapat disimpulkan bahwa EA merupakan gambaran konseptual untuk merencanakan, mendesain, dan mengimplementasikan keterkaitan komponen penyusun organisasi, diantaranya terdiri dari proses bisnis, sistem informasi, teknologi, serta stakeholder yang terlibat di dalamnya yang digunakan untuk menyelaraskan hubungan antara strategi bisnis dengan strategi IT, hasilnya berupa blueprint yang mendokumentasikan semua proses bisnis, sistem informasi, teknologi, serta stakeholder untuk memenuhi visi misi organisasi.

Dalam melakukan perancangan enterprise architecture dibutuhkan framework arsitektur yang sesuai dengan penelitian yang dilakukan. Terdapat beberapa framework yang 
digunakan untuk melakukan perancangan enterprise diantaranya zachman framework, Federal Enterprise Architecture Framework (FEAF), dan The Open Group Architecture Framework (TOGAF). Untuk menentukan penggunaan framework arsitektur pada penelitian ini dilakukan perbandingan beberapa framework yang ditunjukkan pada Tabel I Perbandingan Framework Zachman, FEAF, dan TOGAF [8].

TABEL I

PERBANDINGAN FRAMEWORKZACHMAN, FEAF, DAN TOGAF [8]

\begin{tabular}{|l|c|c|l|}
\hline \multicolumn{1}{|c|}{ Kriteria } & Zachman & FEAF & \multicolumn{1}{|c|}{ TOGAF } \\
\hline $\begin{array}{l}\text { Definisi } \\
\text { arsitektur }\end{array}$ & Parsial & Ya & $\begin{array}{l}\text { Ya, pada tahap } \\
\text { preliminary phase }\end{array}$ \\
\hline $\begin{array}{l}\text { Detail proses } \\
\text { arsitektur }\end{array}$ & Ya & Tidak & $\begin{array}{l}\text { Ya, memiliki fase } \\
\text { ADM }\end{array}$ \\
\hline $\begin{array}{l}\text { Dukungan } \\
\text { terhadap } \\
\text { perubahan } \\
\text { arsitektur }\end{array}$ & Tidak & Ya & $\begin{array}{l}\text { Ya, pada fase } \\
\text { migration planning }\end{array}$ \\
\hline Standarisasi & Parsial & Ya & Ya \\
\hline $\begin{array}{l}\text { Pendukung } \\
\text { bisnis }\end{array}$ & Tidak & Ya & Ya \\
\hline Input teknologi & Tidak & Ya & $\begin{array}{l}\text { Ya, pada fase } \\
\text { architecture } \\
\text { business }\end{array}$ \\
\hline $\begin{array}{l}\text { Model proses } \\
\text { bisnis }\end{array}$ & Ya & Tidak & Ya fase \\
\hline Desain transisisi & Tidak & Tidak & $\begin{array}{l}\text { Ya } \\
\text { Pada preliminary } \\
\text { phase }\end{array}$ \\
\hline Neutrality & & \\
\hline Prinsip arsitektur & & & \\
\hline
\end{tabular}

Berdasarkan pemaparan penjelasan dari jenis framework di atas dapat disimpulkan maka TOGAF dipilih sebagai acuan dalam perancangan EA pada penelitian ini, karena dinilai lengkap dari kriteria dan komponen penyusunannya, serta sesuai dengan kebutuhan pada fungsi SDM Universitas Telkom dibandingkan dengan framework lainnya. TOGAF merupakan framework yang dikembangkan oleh The Open Group's Architecture Framework dan banyak digunakan pada bidang industri manufaktur, perbankan, dan pendidikan. Framework ini memiliki metode dan tools yang detail untuk pengimplementasiannya sehingga membedakan dengan framework EA lainnya. TOGAF dikategorikan dalam empat arsitektur yaitu bisnis, data, aplikasi, dan teknologi [8].

TOGAF Architecture Development Method (ADM) merupakan siklus kegiatan perancangan enterprise architecture yang berulang, terdiri dari tahapan-tahapan yang dibutuhkan dalam mengembangkan arsitektur organisasi meliputi pengembangan konten arsitektur, transisi, dan realisasi arsitektur [9]. Selain itu, TOGAF ADM merupakan suatu metode yang mudah untuk diimplementasikan dan bersifat generik berdasarkan requirements berbagai organisasi, baik di bidang industri maupun bidang akademik seperti perguruan tinggi [10].
TOGAF ADM terdiri dari beberapa fase untuk melakukan perancangan enterprise architecture. Adapun fasefase ADM [9], sebagai berikut :

a. Preliminary Phase

b. Phase A : Architecture Vision

c. Phase $B$ : Business Architecture

d. Phase $C$ : Information System Architecture

e. Phase D : Technology Architecture

f. Phase E : Opportunities and Solutions

g. Phase $F$ : Migration Planning

h. Phase $G$ : Implementation Governance

i. Phase H : Architecture Change Management

\section{METODOLOGI PENELITIAN}

Penelitian ini menggunakan model konseptual sebagai metodenya, dimana model konseptual ini menggambarkan alur penelitian mengenai perancangan enterprise architecture pada fungsi SDM di Universitas Telkom yang didasari oleh permasalahan yang terdapat pada lingkungan Universitas Telkom yang berfokus pada Fungsi SDM, dimana saat ini dalam menjalankan aktivitas bisnisnya penggunaan teknologi informasi belum mampu menyesuaikan kebutuhan bisnis pada fungsi tersebut. Pada beberapa aktivitas bisnis yang dijalankan masih dilakukan secara manual, dimana kebutuhan TI belum mampu memenuhi atau menyelaraskan kebutuhan bisnis. Pelaku yang terlibat dalam lingkungan tersebut adalah pegawai dan unit organisasi. Pendekatan dilakukan melalui serangkaian dokumen rencana strategi, struktur organisasi, visi dan misi, serta SOP. Dalam melakukan penelitian ini menggunakan konsep perancangan EA menggunakan metode TOGAF ADM dan hasil dari penelitian yang berjudul "Perancangan Enterprise Architecture Pada Fungsi Sumber Daya Manusia (SDM) di Universitas Telkom Menggunakan TOGAF ADM". Untuk memperkuat konsep tersebut dilakukan kegiatan wawancara dan observasi untuk mengetahui kendala-kendala yang ada pada fungsi SDM.

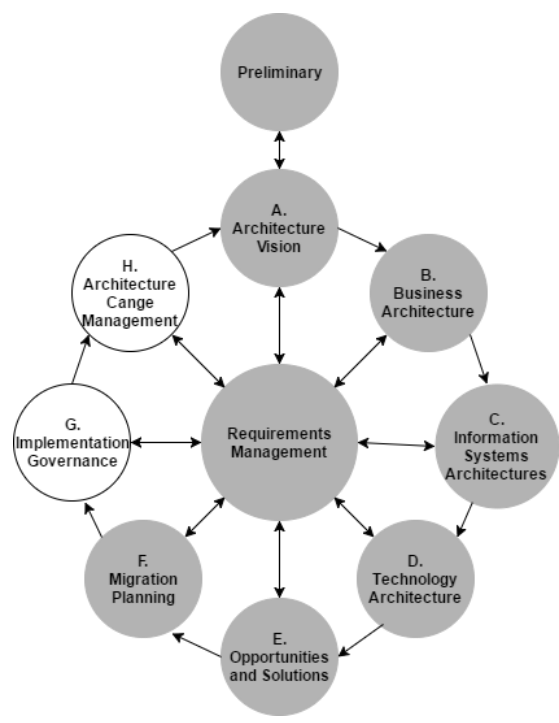

Gambar 1 Kerangka kerja [9] 
Penelitian ini akan menghasilkan sebuah blueprint perancangan enterprise architecture yang terdiri dari artefak, berupa katalog, matriks, dan diagram. Artefak yang dihasilkan berdasarkan fase-fase pada TOGAF ADM dari preliminary phase hingga migration planning. Blueprint EA tersebut dihasilkan dari evaluasi dari hasil penelitian yang berfokus pada Fungsi SDM Universitas Telkom.

Penelitian ini dilakukan pada sebuah lembaga pendidikan swasta yaitu Universitas Telkom. Penelitian yang dilakukan berupa perancangan enterprise architecture dengan menggunakan TOGAF ADM, yang dilakukan dari fase preliminary hingga fase mingration planning ditunjukkan pada Gambar 1 Kerangka Kerja.

Pada penyusunan penelitian ini terdapat langkah-langkah yang dilakukan dalam rangka pemecahan masalah yang digambarkan dalam bentuk sistematika penelitian yang ditunjukkan pada lampiran 1 .

\section{HASIL DAN ANALISIS}

Perancangan enterprise architecture didasarkan pada TOGAF ADM. Pada perancangan ini akan menghasilkan blueprint architecture yang terdiri dari preliminary phase, architecture vision, business architecture, data architecture, application architecture, technology architecture, opportunities and solutions, dan migration planning.

\section{A. Preliminary Phase}

Preliminary phase merupakan tahap awal yang menggambarkan persiapan dan inisiasi kegiatan dalam proses perancangan enterprise architecture.

TABEL II

PRINCIPLECATALOG

\begin{tabular}{|c|c|}
\hline Kategori Principle & Principle \\
\hline \multirow{5}{*}{ Business Principles } & Memaksimalkan keuntungan bisnis \\
\hline & $\begin{array}{l}\text { Manajemen informasi adalah tanggung jawab } \\
\text { semua bagian }\end{array}$ \\
\hline & $\begin{array}{l}\text { Manajemen informasi adalah tanggung jawab } \\
\text { semua bagian }\end{array}$ \\
\hline & $\begin{array}{l}\text { Manajemen informasi adalah tanggung jawab } \\
\text { semua bagian }\end{array}$ \\
\hline & Kepatuhan terhadap hukum hukum \\
\hline \multirow{6}{*}{ Data Principles } & Aset data \\
\hline & Akses data \\
\hline & Data valid \\
\hline & Data realtime \\
\hline & Konsistensi data \\
\hline & Keamanan data \\
\hline \multirow{6}{*}{ Application Principles } & Fleksibilitas aplikasi \\
\hline & Kemudahan penggunaan \\
\hline & Integrasi aplikasi \\
\hline & Support system \\
\hline & Keamanan aplikasi \\
\hline & Hak akses aplikasi \\
\hline \multirow{6}{*}{ Technology Principles } & Interoperability \\
\hline & Mendukung perubahan kebutuhan \\
\hline & Backup infrastruktur teknologi \\
\hline & Keamanan Teknologi \\
\hline & Penggunaan Teknologi secara Realtime \\
\hline & Kontrol Teknik \\
\hline
\end{tabular}

Pada tahap Preliminary phase dilakukan identifikasi prinsip-prinsip arsitektur yang dilihat dari segi bisnis, data, aplikasi, dan teknologi pada organisasi. Prinsip-prinsip arsitektur yang dihasilkan didefinisikan dalam bentuk principle catalog, dimana pendefinisian prinsip-prinsip ini akan mempengaruhi proses perancangan dan digunakan sebagai pendekatan untuk mencapai kesuksesan dalam enterprise architecture yang ditunjukkan pada Tabel II Principle Catalog

\section{B. Architecture Vision}

Architecture Vision merupakan fase awal pada TOGAF ADM yang bertujuan untuk menyelaraskan pandangan mengenai alasan dilakukannya perancangan enterprise architecture dalam mencapai tujuan utama organisasi dan mendefinisikan lingkup perencanaan arsitektur yang akan dibangun pada objek penelitian. Selain itu, architecture vision digunakan untuk mendefinisikan stakeholder beserta peranannya, tujuan bisnis, pemicu strategi bisnis organisasi, serta visi arsitektur pada organisasi. Pada tahap architecture vision menghasilkan beberapa artefak, salah satunya yaitu value chain diagram. Artefak ini digunakan untuk menggambarkan pengelompokkan aktivitas berdasarkan primary activity (aktivitas utama) dan support activity (aktivitas pendukung) dalam menjalankan kegiatan operasional organisasi yang dapat menciptakan nilai dan keunggulan kompetitif bagi organisasi. Pada penelitian ini berfokus pada fungsi Sumber Daya Manusia (SDM) Universitas Telkom yang ditunjukkan pada Gambar 2 Value Chain Diagram.

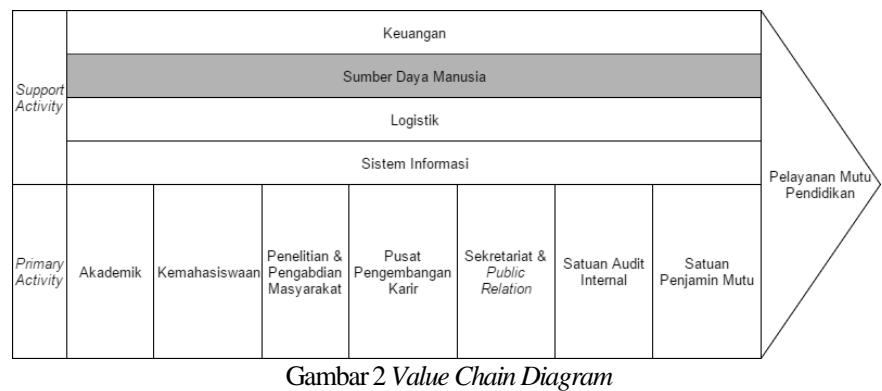

\section{Business Architecture}

Business architecture merupakan penggambaran secara rinci dari apa yang telah dibuat pada fase sebelumnya, yaitu architecture vision. Pada fase ini mendefinisikan strategi bisnis organisasi dan proses bisnis utama pada organisasi untuk menggambarkan kondisi eksisting organisasi tersebut. Perancangan arsitektur bisnis dapat menentukan arsitektur target yang akan dibangun yang diharapkan dapat mencapai strategi bisnis dalam pencapaian tujuan organisasi. Pada fase business architecture menghasilkan beberapa artefak, salah satunya yaitu business service function catalog. Artefak ini digunakan untuk mengidentifikasi layanan-layanan bisnis yang terdapat pada organisasi terkait fungsi bisnis tertentu. Hasil identifikasi layanan-layanan bisnis organisasi didefinisikan pada Tabel III Business Service Function Catalog. 
TABEL III

BUSINESS SERVICE FUNCTIONCATALOG

\begin{tabular}{|l|l|}
\hline \multicolumn{1}{|c|}{ Proses Bisnis } & \multicolumn{1}{c|}{ Service } \\
\hline Pengajuan perencanaan kebutuhan SDM & $\begin{array}{l}\text { Service } \text { perencanaan } \\
\text { kebutuhan SDM }\end{array}$ \\
\hline Pelaksanaan Pelatihan Pegawai & Service pelatihan \\
\hline Rekrutmen Pegawai (Dosen) & $\begin{array}{l}\text { Service } \text { penerimaan } \\
\text { pegawai }\end{array}$ \\
\hline $\begin{array}{l}\text { Pengajuan Jabatan Fungsional Akademik } \\
\text { (JFA) }\end{array}$ & $\begin{array}{l}\text { Service } \text { manajemen } \\
\text { kepegawaian }\end{array}$ \\
\hline $\begin{array}{l}\text { Pengangkatan Tenaga Profesional Full Time } \\
\text { dan Part Time (Dosen dan TPA) }\end{array}$ & $\begin{array}{l}\text { Service } \text { manajemen } \\
\text { kepegawaian }\end{array}$ \\
\hline Administrasi dan Validasi Data SDM & $\begin{array}{l}\text { Service } \text { manajemen } \\
\text { kepegawaian }\end{array}$ \\
\hline Pengelolaan Cuti Pegawai & Service cuti \\
\hline Perjalanan Dinas & Service perjalanan dinas \\
\hline \multirow{2}{*}{ Penggajian (Remunerasi) } & Service penggajian \\
\cline { 2 - 2 } & Service presensi \\
\cline { 2 - 2 } & Service cuti \\
\hline Pengajuan Lembur & Service presensi \\
\hline $\begin{array}{l}\text { Pengajuan Kartu Kesehatan dan Restitusi } \\
\text { Kesehatan }\end{array}$ & $\begin{array}{l}\text { Service } \text { fasilitas } \\
\text { kesehatan }\end{array}$ \\
\hline Pelaporan Keluhan & Service konseling \\
\hline
\end{tabular}

\section{Data Architecture}

Data architecture mendefinisikan entitas data apa saja serta sumber data yang dibutuhkan untuk mendukung fungsi bisnis organisasi. Perancangan arsitektur data dapat menentukan arsitektur target yang diharapkan dapat mencapai strategi bisnis dalam mendukung tujuan bisnis organisasi. Pada tahap data architecture menghasilkan beberapa artefak, salah satunya yaitu data dissemination diagram. Artefak ini digunakan untuk menunjukkan hubungan antara entitas data beserta komponen logikal aplikasi dengan business service dalam organisasi. Diagram ini menggambarkan bagaimana business service memiliki relasi dengan komponen aplikasi beserta entitas data yang dibutuhkan.

\section{E. Application Architecture}

Application architecture merupakan pendefinisikan aplikasi yang digunakan untuk memproses data sehingga menghasilkan aplikasi yang berguna untuk mendukung aktivitas bisnis dalam menyajikan informasi organisasi. Pada fase ini akan dilakukan analisis apakah penggunaan aplikasi relevan terhadap proses bisnis organisasi atau belum untuk menentukan arsitektur target yang akan dibangun. Pada tahap application architecture menghasilkan beberapa artefak, salah satunya yaitu application communication diagram. Artefak ini digunakan untuk menggambarkan relasi antara komponen aplikasi fisikal dengan komponen aplikasi logikal. Pada penggambaran diagram ini akan terlihat hubungan antar aplikasi dengan memperlihatkan komponen aplikasi yang berkaitan satu sama lain.

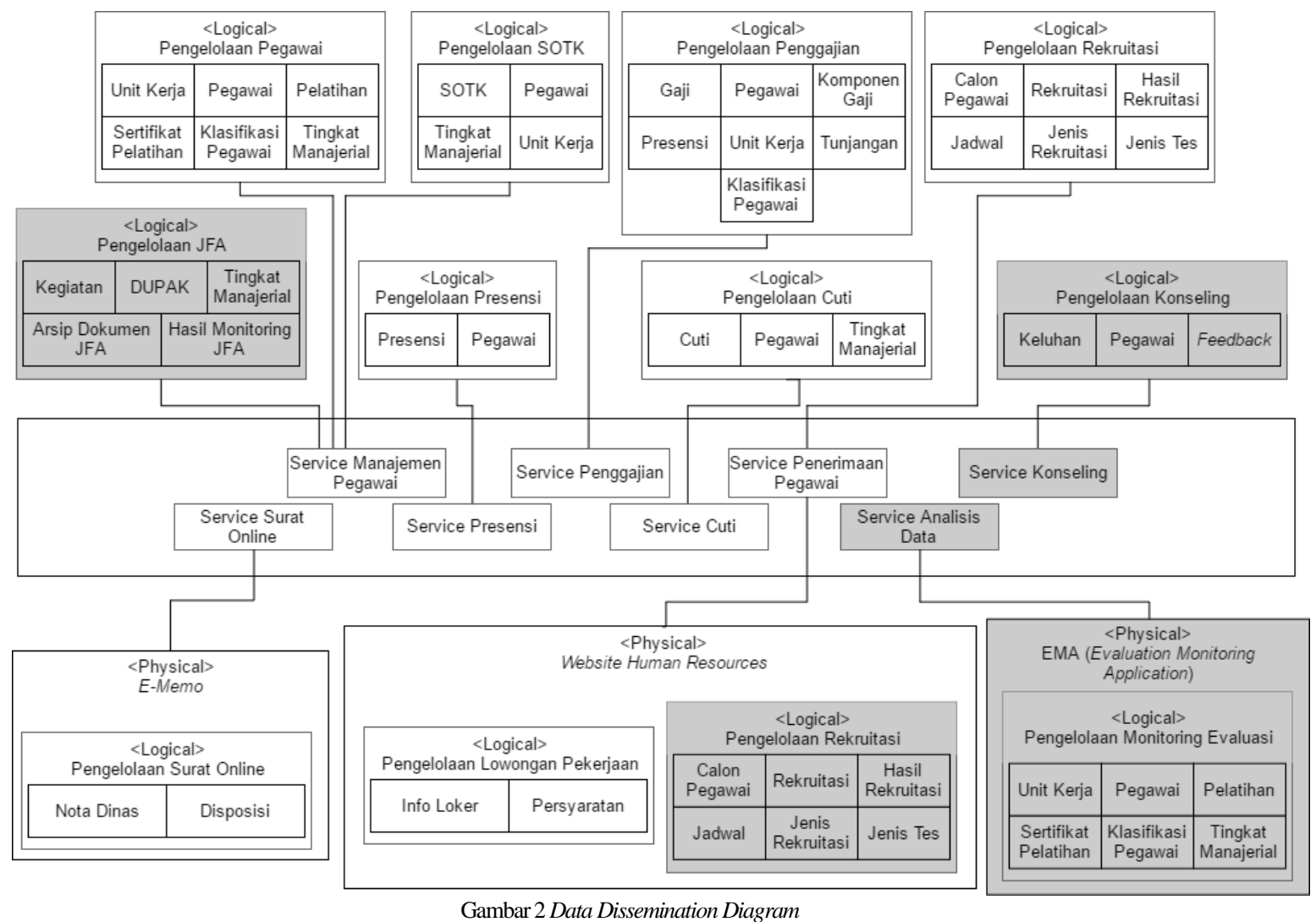




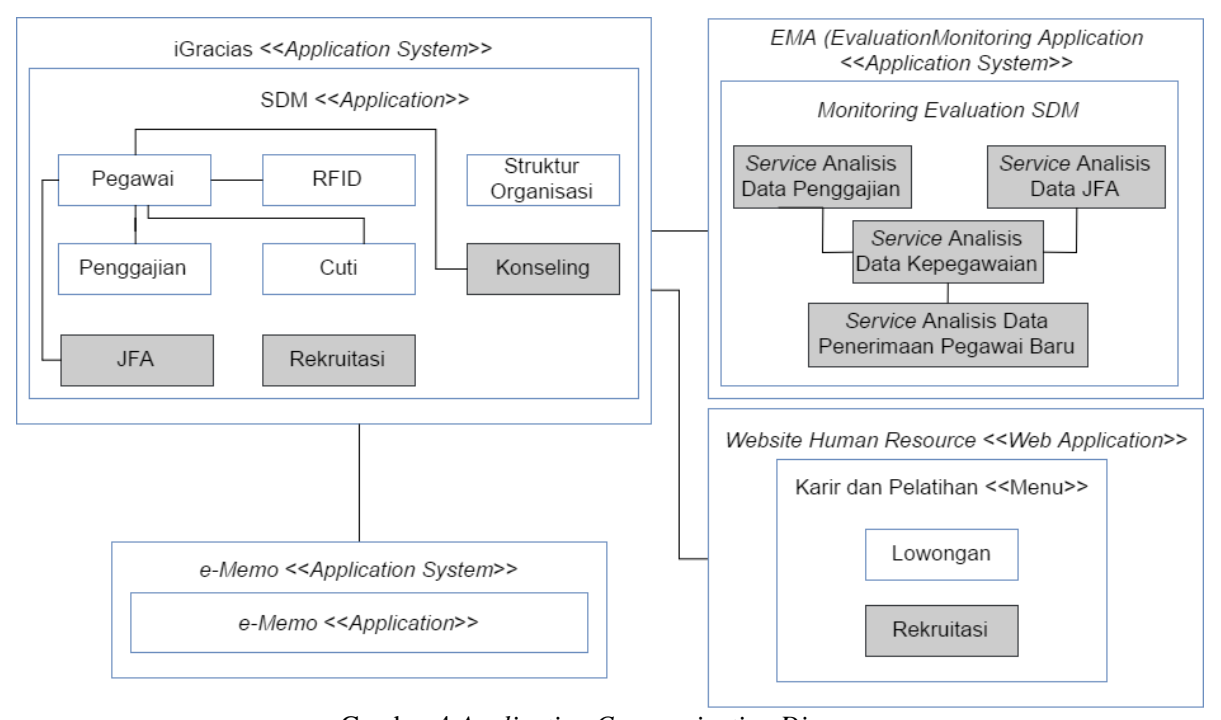

Gambar 4 Application Communication Diagram

\section{F. Technology Architecture}

Technology architecture merupakan pendefinisikan penggunaan teknologi yang mendukung fungsionalitas aplikasi dalam pelaksanaan operasional fungsi bisnis organisasi. Pada fase ini akan dilakukan analisis apakah penggunaan teknologi relevan terhadap aplikasi yang dibangun. Pada tahap technology architecture menghasilkan beberapa artefak berupa, salah satunya yaitu platform decomposition diagram. Artefak ini digunakan untuk menggambarkan platform teknologi yang mendukung arsitektur dan operasional sistem yang mencakup keseluruhan aspek dari platform infrastruktur dan memberikan gambaran dari keseluruhan platform teknologi pada organisasi yang ditunjukkan pada Gambar 5 Platform Decomposition Diagram.

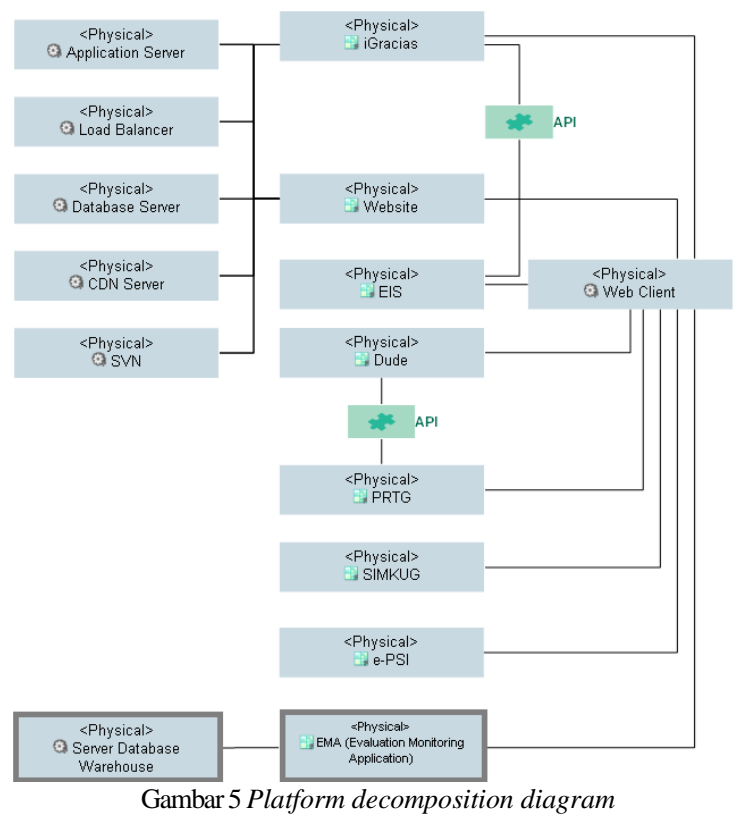

\section{G. Opportunities and Solutions}

Opportunities and solutions merupakan fase TOGAF ADM yang berfungsi sebagai evaluasi atas model perancangan arsitektur yang dibuat. Hasil dari fase ini merupakan dasar dari penyusunan rencana implementasi yang bertujuan untuk mencapai sasaran rancangan arsitektur yang dibangun. Pada tahap opportunities and solutions menghasilkan beberapa artefak diantaranya project context diagram dan benefit diagram. Pada penelitian ini dihasilkan beberapa proyek yang akan dibangun untuk perancangan enterprise architecture. Pendefinisian proyek pada penelitian ini ditunjukkan pada Tabel IV Project Catalog.

TABEL IV

\section{PROJECTCATALOG}

\begin{tabular}{|c|c|c|c|}
\hline Project & Sub Project & Service & Application \\
\hline \multirow{3}{*}{$\begin{array}{l}\text { Pengembangan } \\
\text { website human } \\
\text { resources }\end{array}$} & $\begin{array}{l}\text { Pendokumentasian proses } \\
\text { bisnis dengan SOP. }\end{array}$ & \multirow{3}{*}{$\begin{array}{l}\text { Service } \\
\text { penerimaan } \\
\text { pegawai. }\end{array}$} & \multirow{3}{*}{$\begin{array}{l}\text { Website } \\
\text { Human } \\
\text { Resource }\end{array}$} \\
\hline & $\begin{array}{l}\text { Penambahan fitur } \\
\text { rekruitasi. }\end{array}$ & & \\
\hline & $\begin{array}{l}\text { Integrasi dengan aplikasi } \\
\text { iGracias. }\end{array}$ & & \\
\hline \multirow{5}{*}{$\begin{array}{l}\text { Pembuatan } \\
\text { aplikasi pada } \\
\text { iGracias }\end{array}$} & $\begin{array}{l}\text { Pendokumentasian proses } \\
\text { bisnis dengan SOP. }\end{array}$ & \multirow{5}{*}{$\begin{array}{l}\text { Service } \\
\text { penerimaan } \\
\text { pegawai } \\
\text { Service } \\
\text { konseling } \\
\text { Service } \\
\text { manajemen } \\
\text { JFA }\end{array}$} & \multirow{5}{*}{ iGracias } \\
\hline & Penambahan fitur JFA. & & \\
\hline & $\begin{array}{l}\text { Pengembangan fitur } \\
\text { rekruitasi. }\end{array}$ & & \\
\hline & $\begin{array}{l}\text { Penambahan fitur } \\
\text { konseling. }\end{array}$ & & \\
\hline & Integrasi aplikasi & & \\
\hline $\begin{array}{l}\text { Pengembangan } \\
\text { infrastruktur } \\
\text { teknologi }\end{array}$ & $\begin{array}{l}\text { Penambahan kapasitas } \\
\text { RAM }\end{array}$ & - & - \\
\hline \multirow{2}{*}{$\begin{array}{l}\text { Pembuatan } \\
\text { data } \\
\text { warehouse dan } \\
\text { EMA } \\
\text { (Evaluation } \\
\text { Monitoring } \\
\text { Application) }\end{array}$} & $\begin{array}{l}\text { Pembuatan data } \\
\text { warehouse }\end{array}$ & \multirow[b]{2}{*}{$\begin{array}{l}\text { Service } \\
\text { pelaporan } \\
\text { unit }\end{array}$} & \multirow[b]{2}{*}{$\begin{array}{l}\text { Aplikasi } \\
\text { EMA } \\
\text { (Evaluation } \\
\text { Monitoring } \\
\text { Application) }\end{array}$} \\
\hline & $\begin{array}{l}\text { Pembuatan EMA } \\
\text { (Evaluation Monitoring } \\
\text { Application) }\end{array}$ & & \\
\hline
\end{tabular}




\section{H. Migration Planning}

Migration planning merupakan proses migrasi dengan memastikan rencana pelaksanaan dan melakukan koordinasi migrasi dengan organisasi yang bertujuan untuk mengelola dan menerapkan perubahan portfolio organisasi secara keseluruhan. Pada tahap migration planning menghasilkan beberapa artefak, diantaranya yaitu implementation factor assessment and deduction matrix dan achitecture roadmap.

Implementation factor assessment and deduction matrix digunakan untuk mengidentifikasi faktor-faktor yang akan berpengaruh pada proses implementasi perancangan arsitektur. Dalam proses implementasi perancangan arsitektur organisasi dipengaruhi oleh beberapa faktor, diantaranya risks, issues, assumptions, dependencies, actions, serta impact.

Architecture roadmap berisi mengenai solusi yang ditawarkan yang akan dilakukan beberapa tahun kedepan untuk di implementasikan. Pada Tabel V Architecture Roadmap menunjukkan rencana pelaksaan proyek-proyek yang akan dilakukan dalam perkiraan perhitungan triwulan.

TABEL V

ARCHITECTURE ROADMAP

\begin{tabular}{|c|c|c|c|}
\hline Trivulan I & Trivulan II & Irivulan III & Trivulan $N$ \\
\hline \multicolumn{4}{|c|}{ Penambehan RAM server. } \\
\hline & 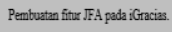 & & \\
\hline & \multicolumn{3}{|c|}{ 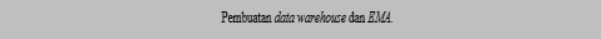 } \\
\hline & & $\begin{array}{l}\text { Pembuatan fitur relmutasi pada website } \\
\text { HR dan integrasi terhadep i Gracias. }\end{array}$ & \\
\hline & & & 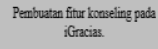 \\
\hline
\end{tabular}

I. Evaluasi Penelitian

Berdasarkan penelitian yang dilakukan evaluasi untuk mengetahui analisis hasil testing pada perancangan enterprise architecture yang ditunjukkan pada Tabel VI Analisa Hasil Testing.

TABEL V

ANALISAHASIL TESTING

\begin{tabular}{|l|c|c|l|l|}
\hline \multicolumn{1}{|c|}{$\begin{array}{c}\text { Komponen } \\
\text { Testing }\end{array}$} & $\begin{array}{c}\text { Bobot } \\
\text { Penilaian }\end{array}$ & $\begin{array}{c}\text { Bobot } \\
\text { Persentase }\end{array}$ & Feedback & Analisis \\
\hline \multicolumn{5}{|c|}{ Bisnis } \\
\hline $\begin{array}{l}\text { Proses bisnis } \\
\text { usulan sesuai } \\
\text { dengan } \\
\text { kebutuhan } \\
\text { bisnis unit. }\end{array}$ & 4 & $80 \%$ & $\begin{array}{l}\text { Usulan } \\
\text { akan dicoba } \\
\text { untuk } \\
\text { diimplemen } \\
\text { tasikan } \\
\text { dalam skala } \\
\text { terbatas. }\end{array}$ & $\begin{array}{l}\text { Kesesuain } \\
\text { terhadap } \\
\text { kebutuhan } \\
\text { proses bisnis } \\
\text { organisasi. }\end{array}$ \\
\hline $\begin{array}{l}\text { Proses bisnis } \\
\text { usulan } \\
\text { mendukung } \\
\text { pencapaian } \\
\text { goal unit. }\end{array}$ & 4 & $80 \%$ & $\begin{array}{l}\text { Usulan } \\
\text { akan } \\
\text { disesuaikan } \\
\text { dengan } \\
\text { kondisi } \\
\text { yang ada }\end{array}$ & $\begin{array}{l}\text { Kesesuaian } \\
\text { proses bisnis } \\
\text { usula dengan } \\
\text { tujuan } \\
\text { strategis } \\
\text { bisnis. }\end{array}$ \\
\hline
\end{tabular}

\begin{tabular}{|c|c|c|c|c|}
\hline $\begin{array}{c}\text { Komponen } \\
\text { Testing }\end{array}$ & $\begin{array}{c}\text { Bobot } \\
\text { Penilaian }\end{array}$ & $\begin{array}{c}\text { Bobot } \\
\text { Persentase }\end{array}$ & Feedback & Analisis \\
\hline \multicolumn{5}{|c|}{ Data } \\
\hline $\begin{array}{l}\text { Kesesuaian } \\
\text { entitas data } \\
\text { usulan } \\
\text { dengan } \\
\text { kebutuhan } \\
\text { data terhadap } \\
\text { proses bisnis } \\
\text { usulan. }\end{array}$ & 4 & $80 \%$ & Setuju & $\begin{array}{l}\text { Identifikasi } \\
\text { entitas data } \\
\text { dapat } \\
\text { memenuhi } \\
\text { requirement } \\
\text { yang ada } \\
\text { dalam } \\
\text { mendukung } \\
\text { pelaksanaan } \\
\text { operasional } \\
\text { bisnis. } \\
\end{array}$ \\
\hline \multicolumn{5}{|c|}{ Aplikasi } \\
\hline $\begin{array}{l}\text { Aplikasi } \\
\text { usulan dapat } \\
\text { mendukung } \\
\text { kegiatan } \\
\text { operasional } \\
\text { bisnis. }\end{array}$ & 4 & $80 \%$ & $\begin{array}{l}\text { Saran, } \\
\text { adanya } \\
\text { pembuatan } \\
\text { aplikasi } \\
\text { JFA untuk } \\
\text { mengelola } \\
\text { data } \\
\text { pengajuan } \\
\text { JFA badi } \\
\text { pehawai. }\end{array}$ & $\begin{array}{l}\text { Usulan } \\
\text { aplikasi } \\
\text { rekruitasi } \\
\text { dan } \\
\text { konseling } \\
\text { saat ini } \\
\text { kurang tepat, } \\
\text { dimana } \\
\text { aplikasi yang } \\
\text { ada hanya } \\
\text { dibutuhkan } \\
\text { pada waktu } \\
\text { tertentu. }\end{array}$ \\
\hline $\begin{array}{l}\text { Aplikasi } \\
\text { usulan dapat } \\
\text { beroperasi } \\
\text { pada } \\
\text { berbagai } \\
\text { platform } \\
\text { teknologi. }\end{array}$ & 4 & $80 \%$ & Setuju & $\begin{array}{l}\text { Usulan } \\
\text { aplikasi } \\
\text { sesuai } \\
\text { dengan } \\
\text { requirement } \\
\text { organisasi } \\
\text { dalam } \text { user } \\
\text { access. }\end{array}$ \\
\hline \multicolumn{5}{|c|}{ Teknologi } \\
\hline $\begin{array}{l}\text { Teknologi } \\
\text { usulan dapat } \\
\text { menanggapi } \\
\text { perubahan } \\
\text { kebutuhan } \\
\text { bisnis. }\end{array}$ & 3 & $60 \%$ & Sedang & $\begin{array}{l}\text { Usulan } \\
\text { teknologi } \\
\text { dapat } \\
\text { menanggapi } \\
\text { kebutuhan } \\
\text { penggunaan } \\
\text { sistem } \\
\text { informasi. } \\
\end{array}$ \\
\hline $\begin{array}{l}\text { Teknologi } \\
\text { usulan dapat } \\
\text { meningkatka } \\
\text { n kinerja } \\
\text { aplikasi. }\end{array}$ & 3 & $60 \%$ & Sedang & $\begin{array}{l}\text { Usulan } \\
\text { teknologi } \\
\text { dapat } \\
\text { memenuhi } \\
\text { requirement } \\
\text { dalam } \\
\text { peningkatan } \\
\text { kinerja unit. }\end{array}$ \\
\hline $\begin{array}{l}\text { Teknologi } \\
\text { usulan dapat } \\
\text { mengurangi } \\
\text { permasalahan } \\
\text { dalam } \\
\text { pengelolaan } \\
\text { database. } \\
\end{array}$ & 3 & $60 \%$ & Sedang & $\begin{array}{l}\text { Usulan } \\
\text { teknologi } \\
\text { dapat } \\
\text { memenuhi } \\
\text { pengelolaan } \\
\text { kapasitas } \\
\text { database. } \\
\end{array}$ \\
\hline
\end{tabular}

\section{KESIMPULAN}

Penelitian ini dilakukan di Universitas Telkom fungsi Sumber Daya Manusia (SDM), dengan melakukan perancangan enterprise architecture menggunakan TOGAF ADM yang terdiri dari fase preliminary hingga migration 
planning. Berdasarkan hasil penelitian yang dilakukan diusulkan beberapa aplikasi yang digunakan untuk mendukung operasional bisnis pada fungsi SDM, diantaranya aplikasi JFA, konseling, dan rekruitasi bagi dosen maupun karyawan. Dengan adanya aplikasi yang diusulkan diharapkan dapat membantu operasional bisnis sehingga dapat berjalan efektif dan efisien. Selain itu, pada arsitektur teknologi diusulkan adanya penambahan RAM untuk meningkatkan performansi aplikasi dan pembuatan BI (Business Intellegence) dengan pembuatan aplikasi EMA (Evaluation Monitoring Application) yang digunakan sebagai aplikasi reporting oleh high-level management Universitas Telkom. Pada penelitian ini menghasilkan sebuah blueprint enterprise architecture dan IT roadmap pada fungsi Sumber Daya Manusia (SDM) di Universitas Telkom.

\section{DAFTAR PUSTAKA}

[1] Olsen, D. H., \& Trelsgard, K. (2016). Enterprise Architecture adoption challenges: An exploratory case study of the Norwegian higher education sector.

[2] Prisyanti, Prasetyo, \& Mulyana, n.d. Perancangan Arsitektur Bisnis dan Arsitektur Data Untuk Layanan Jasa Keuangan PT.XYZ menggunakan TOGAF ADM.
[3] A.Bakar, N. A., S., H., \& Kama, N. (2016). Assessment of Enterprise Architecture Implementation Capability and Priority in Public Sector Agency.

[4] Rijo, Architecture proof of concept in an Portuguese hospital.

[5] http://ccs.is.telkomuniversity.ac.id/division-ofinformation-system/, diakses November 2016.

[6] Arslan, H., Akdemir, A., \& Karsli, M. D. (2013). How Human Resource Operations Work in Higher Education Institutions.

[7] Chief Information Officer Council. (2001). A Practical Guide to Federal Enterprise Architecture version 1.0. Boston: Springfield.

[8] Setiawan, E. B. (2009). Pemilihan EA Framework.

[9] The Open Group. (2011). TOGAF version 9.1 The Open Group Architecture Framework. U.S.: The Open Group.

[10]Yunis, R., \& Surendro, K. (2009). Model Enterprise Architecture Untuk Perguruan Tinggi di Indonesia

[11]telkomuniversity.ac.id: http://telkomuniversity.ac.id/, diakses Oktober 2016 


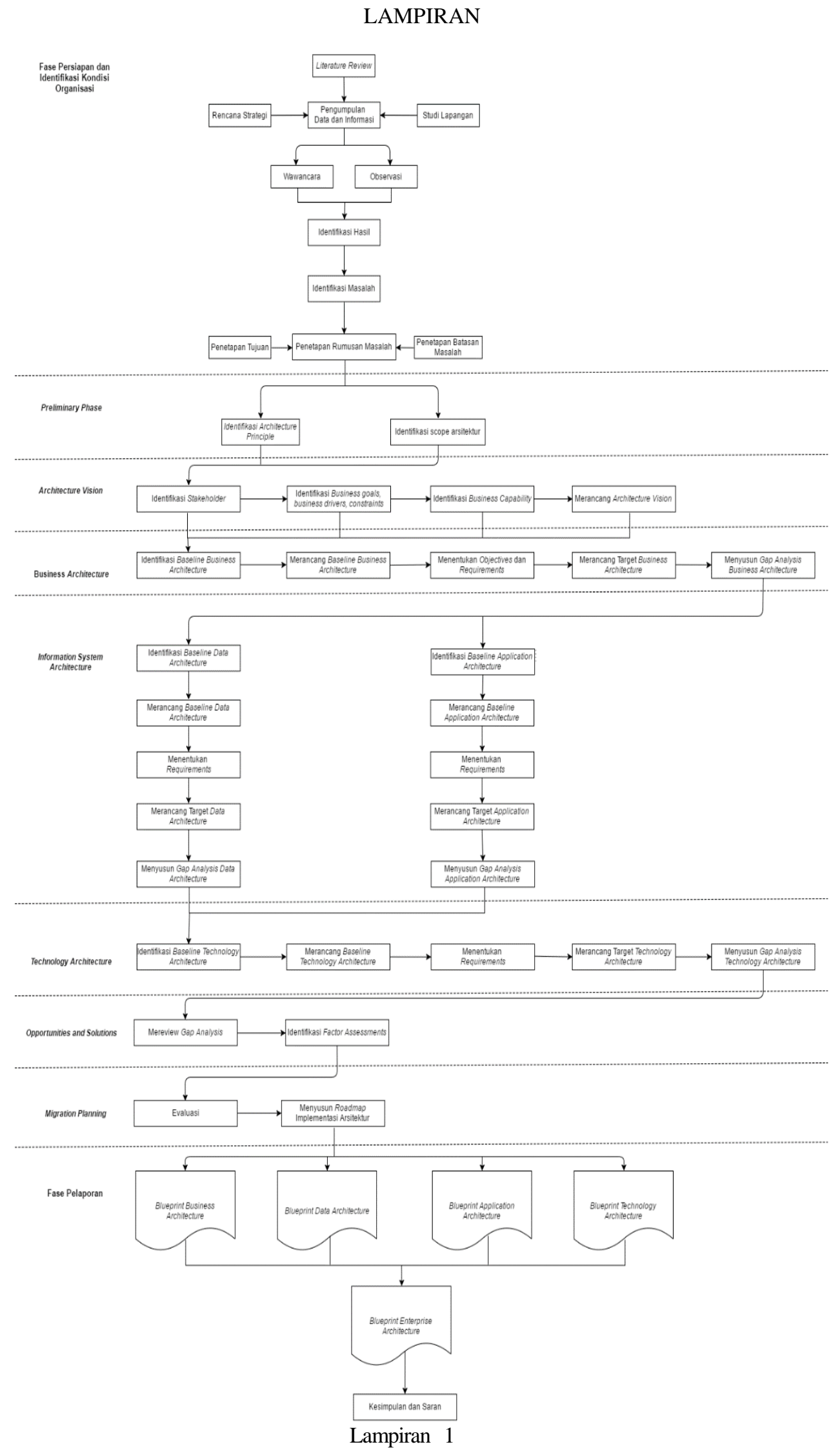

